\section{3rd International Conference on Advanced Research in Teaching and Education}

\title{
The Missing Hub in the Wheel: Improving Ghanaian Basic Schools through Teacher Empowerment
}

\author{
Dandy George Dampson (Ph.D.) \\ Department of Educational Foundations, University of Education, Winneba
}

\begin{abstract}
This study explored the missing element in school improvement among the four types of schools; trapped, dynamic, improved and failing schools. The explanatory sequential design of the mixed-method approach was adopted. Using the proportional stratified random sampling technique, the study sampled 325 respondents made up of 260 teachers and 65 headteachers from the four categories of basic schools in the Central Region of Ghana for the quantitative phase of the study. Subsequently, 15 teachers and 5 head teachers from these categories of schools were sampled purposely for the qualitative phase of the study. Structured questionnaires and semi structured interview guides were used to collect data. The quantitative data were analysed using descriptive (Means and Standard Deviation) statistics whilst the qualitative data were analysed thematically. It was evident from the results that teachers in the improved and dynamic schools are highly empowered than their counterparts in the trapped and failing schools. The teachers in the trapped and failing schools missed out on elements of empowerment such as trusting the expertise of teachers, governance sharing, encouraging autonomy and innovation. The study, therefore, concluded that the missing element in school improvement in Ghana is teacher empowerment. The study recommended that the Ministry of Education and the Central Region Education Directorate should organize pragmatic and purposeful workshops and seminars for teachers and head teachers in trapped and failing schools to be educated on the tenets of teacher empowerment and how it can be used as a tool to improve schools.
\end{abstract}

Keywords: Teacher Empowerment, Trust, Autonomy, Innovation, Creativity 